\title{
SÁNTHA KÁLMÁN
}

\section{A TRIANGULÁCIÓ-TIPOLÓGIÁK ÉS A MAXQDA KAPCSOLATA A KVALITATÍV VIZSGÁLATBAN}

Napjaink kvalitatív társadalomtudományi kutatásmódszertanának egyik kulcskérdése a vizsgálatok sokoldalú felépítése és többrétű értelmezése, az elemezni kívánt ok-okozati viszonyok hálózatszerű feltérképezése. Ehhez kitűnő gondolati és módszertani perspektívát kínál a trianguláció, hiszen a különféle trianguláció-tipológiák segítik a kutatási problémák tudományos igényű feldolgozását, átfogó képet rajzolnak a kutatás tárgyáról, alanyáról, folyamatáról, szerkezetéről. A tanulmány célja a Denzin-féle trianguláció-tipológiák (elméleti, módszertani, személyi, adatok) elemzése, valamint a jelzett típusok számítógéppel támogatott kvalitatív adatelemzésben történő megjelenésének illusztrálása a MAXQDA szoftver segítségével.

\section{Kulcsszavak: trianguláció, MAXQDA, számítógéppel támogatott kvalitatív adatelemzés}

$\mathrm{N}$ igel Fielding és Raymond Lee által az 1990-es évek elején a kvalitatív kutatásmódszertan világába bevezetett számítógéppel támogatott kvalitatív adatelemzés (Computer Assisted Qualitative Data Analysis Software - CAQDAS) (Fielding - Lee, 1991) terminológia ma már a kvalitatív elemzéseket tartalmazó munkák szerves részét képezi. A kvalitatív vizsgálatokra építő tanulmányok kiemelt eleme a trianguláció is, amely a Denzin-féle elméleti, módszertani, személyi, adatok tipologizálás mellett számos kontextusban ismert (Denzin, 1989; Flick, 2008, 2014). A számítógéppel támogatott kvalitatív adatelemzés és a trianguláció lehetséges kapcsolódási pontjainak vizsgálata a multikódolt adatok (szöveg, kép, audio- és videoadat) elemzésére alkalmas szoftverek gyors fejlesztésének köszönhetően állandó témaként jelenik meg a nemzetközi szakirodalmi diskurzusban (Kuckartz, 2012).

A trianguláció napjaink hazai kvalitatív kutatásmódszertannal kapcsolatos köteteiben és tanulmányaiban részletesen megtalálható - lásd legújabban Horváth - Mitev (2015), valamint Sántha (2015) munkáit -, viszont a trianguláció és a számítógéppel támogatott kvalitatív adatelemzés kapcsolatának feltárása továbbra is a tudományos párbeszéd középpontjában áll. A problémakör tanulságos lehet interdiszciplináris vonatkozásban is a különböző tudományterületeken kvalitatív vagy kombinált módszertani hátterű elemzéseket folytatni kívánók számára.

A tanulmány célja a Denzin-féle trianguláció-tipológiák (elméleti, módszertani, személyi, adatok) és a számítógéppel támogatott kvalitatív adatelemzés lehetséges kapcsolódási pontjainak feltárása. Mindezt elsősorban a MAXQDA szoftver alkalmazhatóságának illusztrálásával tesszük, hiszen a szoftver képes a Denzin-féle trianguláció-tipológiák mindegyikének megjelenítésére. Bízunk abban, hogy a tanulmány a Denzin-féle trianguláció-tipológiák elemzésén túl rámutat azon tartalmi csomópontokra is, amelyek átláthatóvá teszik a trianguláció és a számítógéppel támogatott kvalitatív adatelemzés közötti kapcsolatot, valamint arra ösztönzi a kutatókat, hogy egzakt módon jelenítsék meg a trianuláció-tipológiákat a számítógéppel támogatott kvalitatív adatelemzést alkal- mazó empirikus vizsgálataik során. A tanulmány alapvető kvalitatív kutatás-módszertani fogalmak (pl. kódolás, speciális metodológiai elvek) ismeretét feltételezi, ezért ezek magyarázatára nem tér ki.

\section{A triangulációról röviden}

A trianguláció ötlete és elnevezése a korai földmérésekből származtatható. A technika már a nagy német matematikus Carl Friedrich Gaussnál is megjelent, aki 1816-ban azt a feladatot kapta a hannoveri elöljáróktól, hogy pontosan térképezze fel az országot. Minderre katonai célból és pontos adózási alap kimutatása végett volt szükség. A méréseket triangulációs technikával végezte, kiindulásként három hegycsúcs által meghatározott háromszöget használt, amelyet munkatársaival tovább bővített az egész ország területére (Szénássy, 2004).

A trianguláció elnevezése háromszög alakú földmérő eszközre is visszavezethetö, hiszen a régi korok földmüvesei az egzakt és megbízható munka érdekében fából készített háromszög alakú mérőeszközt használtak földjeik felmérésére. A triangulációs technika segítette a tengereken és óceánokon történő navigálást, továbbá feltünt az 1950-es évek geodéziai kutatásaiban is. Újabban tudósítók, katonai stratégák és navigátorok használják olyan trigonometrikus eljárás meghatározására, amellyel egy pont koordinátáinak kiszámításával pontosan megadható tárgyak vagy élőlények pozíciója (Sántha, 2015).

A trianguláció empirikus kutatásokban betölthető funkcióinak vizsgálatánál figyelemreméltó, hogy a kvalitatív kutatásmódszertan a triangulációt használja metaforikusan annak érdekében, hogy ugyanazon jelenség tanulmányozására összetett stratégiákat állapítson meg. Tágabb kontextusban, a kvantitatív terminológia kvalitatív vizsgálatbeli szerepét kiemelö álláspont szerint a trianguláció a kvalitatív vizsgálatok érvényességi biztosítékának tekinthető (Flick, 2008; Sántha, 2009).

Pozitivista értelmezés szerint az érvényesség a mérés fogalmára korlátozódik: azt mérjük, amit mérni szeretnénk (Kvale, 2005). Mérd, ami mérhető, s tedd mérhetővé, 
ami nem az - szól a Galilei óta ismert felhívás, amely akár a kvantitatív és a kvalitatív paradigmák szembenállásának egyik jelmondata is lehetett volna. A kijelentés napjainkra módosult, hiszen ma már elfogadott, hogy a természeti világ megismerésének mintájára a humán valóság nem mérhető és nem tárható fel egzakt módon.

A kutatók többféleképpen látják a kvalitatív vizsgálatok érvényességének biztosítását. A Grounded Theory az érvényesség és a hitelesség zálogának a folyamatos, állandó ellenőrzést, reflektálást tartja (Glaser - Strauss, 1967), míg Miles - Huberman (1994) szerint a kvalitatív vizsgálatok érvényessége többek között a szubjektivitás ellenőrzése, a trianguláció alkalmazása, a szélsőséges esetek vizsgálata, vagy akár az informátorok eredményekre való reflektálása segítségével igazolható.

A kommunikatív érvényesség elve szerint a kutató az érvényesség biztosítása érdekében visszatér a helyszínre annak érdekében, hogy újabb adatgyüjtést végezhessen. Ekkor elméletét az új adatok függvényében továbbfejlesztheti, módosíthatja. A folyamat során Kvale (2005) fontosnak tartja a hogyan (racionális érvelés, narratívák vagy humanisztikus beszélgetés), a miért (miért érvényes a vizsgálat) és a ki (kik kommunikálnak, a partner képes-e elfogadható, őszinte válaszadásra) kérdéseinek megválaszolását. A kommunikatív érvényesség az 1970-es évek óta az egyik legtöbbet vitatott kritérium. A kritikák legfőbb eleme az, hogy a terepre történő visszatérésnél már nincs garancia arra, hogy ugyanolyan körülményeket tudunk biztosítani a vizsgálat számára (Sántha, 2009).

Releváns problémakör a kvalitatív elemzések számára annak eldöntése is, hogy az alkalmazott módszer, valamint az eset kapcsolatban van-e a vizsgálni kívánt kérdéssel („érvényesség ránézésre”). Mindezt kutatói tapasztalatból vagy elméletből tudhatjuk. Például a neveléstudományban általánosan elfogadott, hogy a támogatott felidézés és a kognitív térkép kvalitatív módszerek segítségével feltárható a pedagógusok reflektív gondolkodása.

A trianguláció témakörét nem feltétlenül a klasszikus tengely, a trianguláció - érvényesség - számítógéppel támogatott kvalitatív adatelemzés mentén kívánjuk tárgyalni, ezért is kap kevesebb figyelmet az érvényesség problémaköre. A trianguláció újabb értelmezését helyezzük fókuszba, felhívjuk a figyelmet arra, hogy a többdimenzionalitás a jelenségek, kutatási témák több perspektívából való láttatása vezethet el a kvalitatív elemzések szisztematizálásához. Ebben a többdimenziós megközelítésben a triangulációval összefüggésben megjelennek a megbízhatóság kérdései is (például a személyi triangulációnál Sántha, 2013, 2015).

Bár klasszikus értelemben a trianguláció a kvalitatív kutatások leggyakoribb érvényességi biztosítékának tekinthető, szerepe a kutatók között sem egyértelmüen elfogadott. Flick (2005) szerint a trianguláció inkább csupán alternatíva az érvényességhez, hiszen a vizsgált jelenségek különböző variációihoz kínál megközelítést. Az utóbbi évtized nemzetközi szakirodalma a trianguláció alternatívájaként, a többféle megközelítés szimbólumaként a kristályosítás fogalmát is használja (Richardson, 2000; Verd - Porcel, 2012), valamint ugyanebben a megközelí- tésben feltünik a hálózás terminológia is (Mason, 2009). A hálózatok témaköre a számítógéppel támogatott kvalitatív adatelemzés során is tetten érhető, például a legújabb szoftverek képesek a többféle megközelítés vizuális megjelenítésére és kezelésére, különféle linkkapcsolatok kreálására. Ehhez kiváló terepet biztosít a szoftverek fogalmi szintje, ahol például az elméletgenerálás, vagy akár az adat-trianguláció is tetten érhető (pl. geo-linkek csatolása egy elméleti koncepcióhoz - lásd erről a szoftverek és a trianguláció kapcsolatát tárgyaló fejezetrészben).

A Grounded Theory társadalomtudományi kutatásokban történő megjelenésével (Glaser - Strauss, 1967), majd Denzin munkásságának köszönhetően a trianguláció egyre nagyobb figyelmet kapott a tudományos közösségekben, és már körvonalazódni látszódtak markáns, megoldásra váró módszertani problémák is. Például, az 1970-es évek amerikai és nyugat-európai társadalomtudományi vizsgálataiban a kvantitatív és kvalitatív módszerek kombinációja során a módszerek kombinációja (Mixed Methods) és a trianguláció között nem volt egyértelmü különbségtétel (Ackel-Eisnach - Müller, 2012; Sántha, 2015). A trianguláció teoretikus és módszertani bázisának kidolgozásához nagymértékben hozzájárultak Lamnek (2005) és Flick $(2008,2014)$ munkái, mindkét szerző a trianguláció összetett jellege mellett foglalt állást és hirdette, hogy a trianguláció több a különböző módszerek kombinálhatóságánál.

\section{Trianguláció-tipológiák}

A tanulmányban a trianguláció-tipológiákat a Denzin-féle értelmezés szerint használjuk, ezért elméleti, módszertani, személyi és adatok triangulációja között teszünk különbséget (Denzin, 1989; Flick, 2008). A különbségtétel vázlatos ábrázolása szükséges a trianguláció és a számítógéppel támogatott kvalitatív adatelemzés kapcsolatának feltérképezéséhez. Denzin (1989) a többszörös trianguláció elnevezést is használja, amely az általa meghatározott trianguláció-típusok ugyanazon kutatási projektben történő alkalmazását preferálja. Álláspontjával azonos elven alapul a Flick (2005) által használt szisztematikus perspektív trianguláció is, amely az adatok, a személyi, a módszertani és az elméleti trianguláció elemeit ötvözi. A továbbiakban a Denzin-féle tipológiák elemzése és néhány neveléstudományi jellegü példa illusztrálása mellett olyan gyakorlati relevanciájú kérdéseket és problémákat is felvetünk, amelyek átgondolása segítheti a triangulációt alkalmazó kvalitatív vizsgálatok kivitelezését.

\section{Elméleti trianguláció}

Az elméleti trianguláció több különböző elméleti koncepció alkalmazásának szükségességét hangoztatja a vizsgálat során. Minden projekt többféle elméleti háttérrel rendelkezhet, a tézisek ütköztetése, a köztük lévő kapcsolatok keresése, vagy akár a teóriák újragondolása is mozgathatja a kutatás folyamatát. Az elméleti triangulációra példaként szolgál, amikor újgenerációs oktatási módszerek (pl. kooperatív technikák, projektmódszer) tanulók általi elfogadottságának vizsgálatánál különböző tanuláselmé- 
leti koncepciók alapján vizsgálódunk, hiszen így választ kaphatunk a tanulás, az eredményesség, a tanórai közreműködés közötti összefüggések mibenlétére. Így a klaszszikus pedagógiai háromszög tanár - tanuló - tananyag kapcsolatrendszere is vizsgálható. Továbbá a tanulói eredményesség elemzésénél különböző motivációs elméletek alkalmazása is segíti az elméleti trianguláció érvényre jutását (Sántha, 2015). Az elméleti trianguláció alkalmazása során átgondolandó, hogy amennyiben különböző teóriák alapján vizsgálódunk, a vizsgálat tárgyát mennyiben lehet az alkalmazott teoretikus bázis alapján pontosan magyarázni.

\section{Módszertani trianguláció}

A módszertani trianguláció a trianguláció-tipológiák központi koncepciója, kiemelt figyelem illeti. Alkalmazása azon elven alapul, hogy a kutatási módszerek korlátozhatják a vizsgálatot, nincs egyértelmüen jó, megfelelő módszer, ezért ahol lehet, indokolt minél több módszertani bázisra építeni a vizsgálatot. Azonban pusztán a menynyiségre törekvés, a minél több módszer kutatási projektben történő használata nem feltétlenül vezet eredményre. Nézzük, hogy miért!

A módszertani trianguláció-tipológiák esetén megkülönböztethető a módszerek közötti (Between Method vagy Across Method) és a módszeren belüli (Within Method) trianguláció. A módszerek közötti trianguláció két vagy több olyan különböző módszer alkalmazását jelenti, amelyek összehasonlítható vagy kongruens adatokat generálnak. Sokszor pusztán ezt a típust azonosítjuk és használjuk triangulációs technikaként, Denzin (1989) is a módszertani trianguláció e változatát tartja leginkább figyelemreméltónak. A módszeren belüli trianguláció egy módszeren belül különböző technikák alkalmazását jelenti, használata akkor célszerü, ha egy módszeren belüli különböző megközelítések szisztematikusan alkalmazhatók és elméletileg jól megalapozottak (lásd részletesen Sántha, 2015 kötetét).

A módszerek közötti triangulációra adható példáknál célszerű a kvantitatív-kvalitatív, valamint a kvalitatív-kvalitatív módszertani párosításra kitérni. Kvantitatív-kvalitatív kombináció esetén tipikus a kérdőív és a különféle interjútípusok, vagy a kérdőív és a megfigyelés kombinációja. Például egy iskola tanulóinak virtuális környezetekkel, webes tanulási felülettel kapcsolatos nézeteinek feltárásához kitűnő a kérdőív és a fókuszcsoportos interjú párosa, de a téma feltárására alkalmas lehet az esettanulmány és a kérdőív társítása is. Továbbá az osztálytermi kommunikáció kutatására az interakció-elemzés különféle típusai kísérletekkel vagy megfigyelésekkel társítva is használhatók.

A kvalitatív-kvalitatív kombinációt tekintve a pedagógusok reflektív gondolkodásának vizsgálatánál sikeres a támogatott felidézés és a kognitív térkép kombinálása, valamint a tanárrá válás folyamatának elemzésénél eredménnyel járhatunk például a mélyinterjú és a kötetlen reflektív napló társításával is. Továbbá az iskola architektúráját, térelrendezését, tanulási környezetét, saját tereit vizsgáló kutatásban a fotóinterjú alkalmazása a módszer összetett technikai rendszerének köszönhetően eleget tesz a módszeren belüli trianguláció követelményeinek (Sántha, 2015).

E gondolatok alapján is látható, hogy a módszertani trianguláció talán a trianguláció-tipológiák legvitatottabb pontjaként kezelhető. A módszerek közötti trianguláció alkalmazásakor felmerülhet a kérdés, hogy egy objektum vizsgálatához miként választhatók ki különböző módszerek, honnan tudható, hogy a kiválasztott módszerek ugyanazon probléma feltárására alkalmasak. Nem zárható ki olyan jelenségek, szituációk vizsgálata sem, ahol csak egy módszer célravezető: ekkor figyeljünk olyan kvalitatív technikákra, amelyek összetett jellegük miatt önmagukban eleget tesznek a módszertani trianguláció követelményének ( $\mathrm{pl}$. fotóinterjú, Seidman-féle mélyinterjú), valamint térjünk vissza a tervezési fázishoz és szükség esetén gondoljuk át a trianguláció kivitelezését. A módszeren belüli trianguláció felveti az ugyanazon adatkorpuszon két vagy több technika használatával kapott eredmények összehasonlíthatóságának problémáját is.

A kutatók helyzetét nem egyszerüsíti az sem, hogy a kvalitatív vizsgálatok egyedi, látszólag „egzotikus” módszerei nehezen kezelhetők sokaságuk és elemzési lehetőségeik végett (Kuckartz, 2012). Állítása alátámasztására Kuckartz a Norman Denzin alapításával Urbana-ban (USA) évente megrendezett International Congress of Qualitative Inquiry konferencia (www.icqi.org) absztraktjainak áttekintését javasolja, továbbá informatív lehet a Berlinben évente sorra kerülő Berliner Methodentreffen (www.berliner-methodentreffen.de) interdiszciplináris konferencia anyagainak figyelembevétele is. Hasonló problémát vet fel a Tesch (1992) által említett közel ötven különböző kvalitatív technika, valamint azok elemzési módjaiból kiolvasható sokszínűség is.

\section{Személyi trianguláció}

A személyi trianguláció a kvalitatív vizsgálat szubjektivitásával járó torzító hatások minimalizálása érdekében több kutató, elemző bevonását feltételezi a kutatás folyamatába (igaz ez főleg az adatgyűjtés- és elemzésre, kódolásra). Vagyis ugyanazon jelenség különböző személyek általi vizsgálatát szorgalmazza, hiszen az adatok és az eredmények más kutatótársakkal történő megvitatása hozzájárulhat az elmélet, az adatértelmezés vagy akár az egész elemzési folyamat korrigálásához, segítheti az elméletgenerálást is.

A személyi triangulációra adható tipikus neveléstudományi jellegü példák egyike a következő: egy osztálytermi bemutatóóra mozzanatait több pedagógus megfigyeli, majd a kapott adatokat összehasonlítják. Itt kulcskérdés a megfigyelési szempontsorral (kötött), illetve a szempontsor nélkül (kötetlen) történő vizsgálatok szétválasztása, hiszen utóbbinál a szubjektív hatások torzító jellegével találkozunk. A megfigyelési szempontsor alkalmazása is rejthet problémákat, hiszen az adatrögzítés során sok függ a kutató észlelésétől, korrekt és gyors helyzetértékelésétől és a megfigyeltek tények rögzítésétől. Továbbá a kutatási praxisban gyakran előforduló eset, amikor az interjú átiratát több elemző ugyanazon kódolási logika és szisztéma 
alapján kódolja, majd a kapott kategóriákat összehasonlítják. Ekkor a kódolás megbízhatóságával kapcsolatos információkhoz juthatunk (lásd erröl Sántha, 2013).

A személyi triangulációra vonatkozó központi probléma, hogy mennyiben generálhat egy kutatási módszer összehasonlítható adatokat akkor, ha az adott módszert különböző személyek alkalmazzák, így az alkalmazásból esetleg eredhetnek szubjektivitásra is okot a problémák (pl. osztályteremben folytatott kötetlen megfigyelés különböző személyekkel).

\section{Adatok triangulációja}

Általános értelmezés szerint az adatok triangulációja eltérő időpontban és helyen, különböző forrásból, eltérő személyektől, valamint más technikai megvalósítással gyüjtött adatokkal való munkát jelenti. Így időbeli, térbeli és személyi dimenziók különíthetők el.

Időbeli dimenzió biztosítására megfelelő lehet, ha egy újgenerációs oktatási módszer tanulók általi elfogadottságának vizsgálata során különböző időpontokban gyüjtünk adatokat. Térbeli dimenziónál iskolai architektúra témakörben folytatott vizsgálat során egy intézményre vonatkozóan különböző helyekről gyüjtött információkkal dolgozunk. A személyi dimenzió figyelembevételekor például a pedagógus által alkalmazott újgenerációs oktatási módszerek didaktikai aspektusainak vizsgálatakor az elemzésbe különböző tanulói csoportok, osztályok vonhatók be (Sántha, 2015).

Az adatok triangulációjának időbeli dimenziójánál felmerülő kérdés, hogy ha a vizsgálat tárgyát két különböző időpontban elemezzük, akkor az az eltérő időpontokban vajon ugyanazon ismertetőjegyeit mutatja vagy sem (lásd az osztálytermi kutatásokat, ahol az osztály eltérő időpontokban különböző arcát láttatja). A térbeli dimenziónál hasonló a helyzet, hiszen ugyanarra a vizsgálati tárgyra vonatkozóan a különböző helyről gyüjtött adatok sem biztos, hogy ugyanazon jellemzöket, ismertetőjegyeket hordozzák. Ezt nem is indokolt megkövetelni akkor, ha a triangulációt az adatok különböző perspektívából való láttatásának eszközeként értelmezzük. A személyi dimenzió alkalmazása során felmerülhet a kérdés, hogy minden esetben megoldható-e a különböző személyektől történő adatgyüjtés.

A trianguláció-típusok közötti különbségek és párhuzamok áttekintését az 1. táblázat segítheti.

Lényeges kérdés annak eldöntése is, hogy a trianguláció-tipológiák alkalmazásakor „és”, illetve „vagy” kapcsolatépítés szükséges-e a típusok között. Elfogadott álláspont szerint a trianguláció-tipológiák közötti „,vagy” kapcsolatot építve is müködik a trianguláció, bár nem a teljes megvalósulás értelmében. Ilyenkor csak egy típust, például a módszertani vagy a személyi triangulációt alkalmazzuk. Mindezt célszerü a vizsgálat dokumentációja során egyértelműen rögzíteni. A típusok kombinálásakor („és” logikai kapcsolattal) egyértelmü a trianguláció jelenléte, hiszen így akár az összes tipológia is felvonultatható a kutatásban.

\section{A trianguláció és a kombinált módszertan közötti különbségek}

Ebben a fejezetrészben azt a problémakört kívánjuk feltárni, amely a trianguláció és a kombinált módszertan (Mixed Methods) közötti hasonlóságokra és alapvető különbségekre mutat rá. Így válasz adható arra a kérdésre is, hogy lehet-e éles határvonalat húzni a trianguláció és a kombinált módszertan közé? Mindez releváns probléma, a válasz segítheti az empirikus vizsgálatok tervezését és kivitelezését.

A társadalomtudományi kutatásmódszertan különbséget tesz a több módszertant használó kutatás (Multimethods Research) és a kombinált, kevert módszertanon alapuló kutatás (Mixed Methods Research) között (Király és mtsai, 2014; Kuckartz, 2014). A Multimethod Research fogalma az 1950-es évekre, Campbell és Fiske által konstruált MTMM mátrixhoz

Trianguláció-tipológiák

\begin{tabular}{|c|c|c|}
\hline \begin{tabular}{|c|}
$\begin{array}{c}\text { Trianguláció- } \\
\text { tipológia }\end{array}$ \\
\end{tabular} & Altípus & Meghatározás \\
\hline Elméleti & - & $\begin{array}{l}\text { Egy jelenség, szituáció, objektum, személy, csoport, tárgy különbözö elméleti } \\
\text { koncepciók alapján történő elemzése. }\end{array}$ \\
\hline \multirow[t]{2}{*}{ Módszertani } & $\begin{array}{c}\text { Módszerek közötti (Between } \\
\text { Method, Across Method) }\end{array}$ & $\begin{array}{l}\text { Egy jelenség, szituáció, objektum, személy, csoport, tárgy vizsgálatakor legalább két } \\
\text { különböző módszer alkalmazása. }\end{array}$ \\
\hline & $\begin{array}{l}\text { Módszeren belüli (Within } \\
\text { Method) }\end{array}$ & $\begin{array}{l}\text { Egy jelenség, szituáció, objektum, személy, csoport, tárgy vizsgálatakor egy módszert } \\
\text { használunk, de a módszeren belül különbözö technikákat alkalmazunk. }\end{array}$ \\
\hline Személyi & & $\begin{array}{l}\text { Egy jelenség, szituáció, objektum, személy, csoport, tárgy vizsgálatakor az } \\
\text { adatgyüjtésben és elemzésben különböző személyek vesznek részt. }\end{array}$ \\
\hline \multirow[t]{3}{*}{ Adatok } & Időbeli dimenzió & $\begin{array}{l}\text { Egy jelenség, szituáció, objektum, személy, csoport, tárgy vizsgálata legalább két } \\
\text { különböző időpontban történik. }\end{array}$ \\
\hline & Térbeli dimenzió & $\begin{array}{l}\text { Egy jelenséggel, szituációval, objektummal, személlyel, csoporttal, tárggyal kapcsolatos } \\
\text { adatgyüjtés legalább két különböző helyen történik. }\end{array}$ \\
\hline & Személyi dimenzió & $\begin{array}{l}\text { Egy jelenséggel, szituációval, objektummal, személlyel, csoporttal, tárggyal kapcsolatos } \\
\text { adatgyüjtés során különböző alanyoktól gyűjtött információkat, adatokat jelenti. }\end{array}$ \\
\hline
\end{tabular}


nyúlik vissza. Ebben a kontextusban a „,multimethod” több olyan módszer alkalmazását jelenti, amelyek ugyanazon kvantitatív vagy kvalitatív módszercsaládhoz tartoznak. A több módszer használata úgy is megvalósítható, hogy ugyanazon projektben több kvalitatív (pl. támogatott felidézés és kognitív térkép a pedagógusok reflektív gondolkodásának feltárására), vagy több kvantitatív módszert alkalmazunk (pl. két standardizált tesztet). A kombinált paradigma (Mixed Methods) esetén módszertani szempontból fókuszban a kvantitatív és a kvalitatív módszerek összehangolása és tervszerü alkalmazása, kombinációja áll. A témakör részletes tárgyalása az 1980-as, 1990-es években kezdődött, kitüntetett figyelem övezte a kvantitatív és kvalitatív módszerek kombinálhatóságával kapcsolatos modellek fejlesztését (Király és mtsai, 2014; Kuckartz, 2014; Sántha, 2015). Mindezek alapján indokolt megjegyezni, hogy a kombinált vizsgálat nem ekvivalens a több módszert alkalmazó vizsgálattal.

A különbségek kérdéséhez visszatérve állítjuk, hogy nem létezik éles határvonal, de definíció szintjén lehetséges a különbségtétel. Kombinált módszertan esetén az adatgyüjtő eszközök, módszerek különböznek, hiszen a kvantitatív és a kvalitatív paradigmából is használunk módszereket (a szekvencialitás vagy a párhuzamos alkalmazás ebből a szempontból nem lényeges), továbbá a trianguláció az adatok különböző perspektívából való láttatásának eszközeként értelmezhető. Ezért a trianguláció komplexebb a kombinált módszertannál, egyaránt figyel a kutatás szerkezetére és gyakorlatára. A kutatók egy része a triangulációt paradigmafüggetlennek vélik, így a kvalitatív és a kvantitatív paradigmán átívelőnek tartják. Állítják, hogy a trianguláció az „új paradigma” (a harmadik, a kevert, kombinált) kialakításánál is szerepet játszik (Kuckartz, 2014). További markáns különbség, hogy a trianguláció jelentheti csupán egy tipológia alkalmazását is, például elméleti vagy személyi trianguláció használatát is, így ezért sem lehet ekvivalens a kevert módszertannal, ahol fókuszban a módszerek tervszerü használata, kombinálása áll.

Elfogadva azt a tényt, hogy a trianguláció nem ekvivalens a kombinált módszertannal, problémát generál, hogy a trianguláció része lehet-e a kevert módszertannak, vagy pedig fordítva igaz a kérdés, a kombinált módszertan része a triangulációnak. A kombinált paradigma képviselői nem értenek egyet azzal, hogy a kevert paradigma a trianguláció részhalmaza lenne. Azzal érvelnek, hogy a trianguláció a validálás technikája, míg a kombinált módszertan olyan továbbvezető koncepció, amelyben nem a validálás és a mérés, hanem a kutatási problémához megfelelő módszerválasztás kerül előtérbe (Kuckartz, 2014).

A különféle módszerek egymáshoz való viszonyának tárgyalása mellett indokolt röviden kitérni a különféle paradigmák (kvalitatív, kvantitatív, kombinált) kapcsolatának problematikájára is. Először Dilthey fogalmazott meg olyan szempontokat, amelyek még inkább kihangsúlyozták a majdani kvantitatív és kvalitatív koncepciók különbségeit. A két paradigma egymás melletti élete nem volt felhőtlen, ezt mutatják az évtizedekre visszanyúló álláspontok is.
Az ellenző diverzitáselmélet képviselői szerint a kvantitatív és a kvalitatív paradigmák összeegyeztethetősége teljes mértékben kizárt, hiszen a különböző módszerek és technikák együttes alkalmazása bármilyen kutatási témakörben elképzelhetetlen (Smith-Heshusius, 1986). Az elmélet képviselői kategorikusan állást foglalnak például a kvantitatív lineáris és a kvalitatív ciklikus folyamatok mellett, ezzel is nyomatékosítva a különbségtétel igényét. A kvantitatív és a kvalitatív módszerek kombinálását megkérdőjelező nézetek fö irányelve az, hogy a kvantitatív és a kvalitatív kutatásokat nemcsak a különböző módszerek választják el egymástól, hanem a két paradigma kultúrájuk által alapvetően különböző. Ez a megkülönböztetés a módszerekben ölt testet (Reichertz, 2009). A napjainkban elfogadottá vált kiegészítő diverzitáselmélet képviselői szerint a kvantitatív és a kvalitatív paradigmák egymás kiegészítői, mert a vizsgálatok céljai határozzák meg azt, hogy melyik megközelítés lehet eredményesebb. A különbözö elméleti, filozófiai hátterü módszerek komplementerként viselkednek, mindegyik lényeges információt hordozhat a vizsgált jelenséggel kapcsolatban. Az egységelmélet képviselői nem tartják kategorikusan szétválaszthatónak és összeegyeztethetetlennek a kvantitatív és a kvalitatív paradigmát. E nézet szerint egyetlen paradigma létezik sok egymást kiegészítő módszertani megközelítéssel (Sántha, 2011). A kvantitatív és a kvalitatív paradigmák mellett az elmúlt évtizedekben feltűnt a kevert, a kombinált módszertani paradigma is. Egyszerű megfogalmazás szerint, a kombinált módszertani vizsgálatok kvalitatív és kvantitatív adatgyüjtést, valamint elemzési technikákat alkalmaznak párhuzamos vagy szekvenciális módon. Elönyük, hogy segítik a kutatási kérdésekre adható minél pontosabb és részletesebb válaszok megfogalmazását, következtetések levonását. Látható, hogy ebben a kontextusban a módszertani trianguláció is kiemelt szerepet kap, továbbá a modern szoftverek is alapoznak a kevert módszertan által kínált lehetőségekre (Sántha, 2015).

\section{A trianguláció és a kutatási korlátok}

A triangulációt alkalmazó vizsgálatok esetén is releváns lehet a kutatási korlátok figyelembevétele. Az időbeli korlát tipikus jellemző, mert a különböző módszerek alkalmazása, az adatgyűjtés jelentős időt vehet igénybe, amivel célszerü kalkulálni már a tervezés során (Flick, 2014). Továbbá az adatrendezés is időbeli problémákat generálhat, hiszen a sokszor jelentős méretủ kvalitatív adatkorpuszt elemezhető formába kell önteni. Itt elsősorban az interjúk szövegadatainak megjelenítésére gondolunk, hiszen interjú-átiratokkal dolgozunk, ezek képezik a kódoláshoz szükséges anyagot. Mindez időt és az átírási rendszerek (lásd erröl Kuckartz, 2012; Silverman, 2004), valamint az átírást segítő szoftverek ismeretét igényli (pl. f4 szoftver www.audiotranskription.de/f4.htm -, melynek adatai importálhatók a MAXQDA újabb verzióiba is). A MAXQDA lehetővé teszi az audioanyagok közvetlen kódolását is, így kutatótól függ, hogy az átírt szöveges adatokat kódolja, vagy direkt a hanganyagok kódolásához lát hozzá. Az át- 
írás során az időfaktor összefüggésbe hozható az anyagi korláttal is, ha az interjúk átírását külső személy végzi. Ez nem tanácsos, hiszen átíráskor ismerkedünk a szöveggel, formálódhatnak tartalmi kategóriák, az elsődleges „kódolás" már kialakulhat bennünk, ami segíti az elemzés menetét.

Az időbeli korlátok mellett releváns a személyi korlát figyelembevétele is. A technika alkalmazása különböző kutatói kompetenciákat igényelhet, a vizsgálatba bevont kutatók, kutatói csoportok számára mindez valós problémaként jelentkezhet, akkor, ha a felkért kutatók különböző módszertani ismeretekkel rendelkeznek, vagy nem eléggé jártasak az adatelemzést segítő szoftverek világában. Ezért célszerü előzetes felkészítésen, megbeszélésen részt venniük a kutatóknak, ahol a vizsgálattal kapcsolatos minden felmerülö problémára választ kaphatnak.

\section{Trianguláció a számítógéppel támogatott kvalitatív adatelemzés gyakorlatában}

A kutatási gyakorlat számára releváns kérdés, hogy a számítógéppel támogatott kvalitatív adatelemzés során hol és milyen trianguláció-tipológia alkalmazására van lehetőség (1. ábra).

1. ábra

Trianguláció és a számítógéppel támogatott kvalitatív adatelemzés

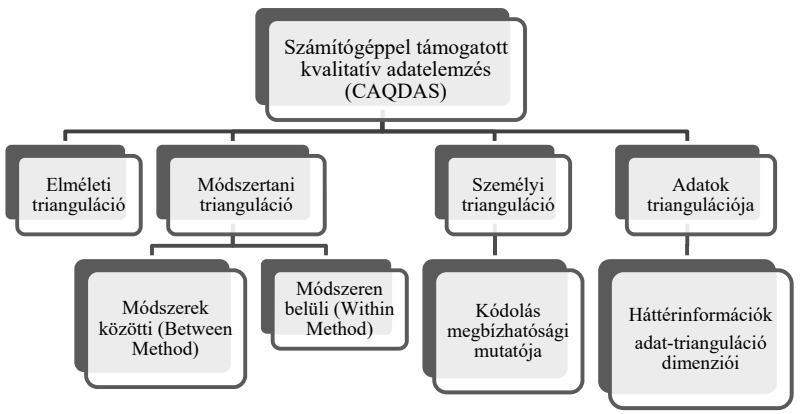

Forrás: Sántha $(2015,93$. o.)

Az elméleti trianguláció absztrakt szinten való jelenléte a számítógéppel támogatott adatelemzésben trivialitás, hiszen bármilyen szoftver az adatelemzés többszempontú teoretikus hátterét biztosítja. Így van ez a MAXQDA esetén is, amely figyelembe veszi a társadalmi jelenségek egynél több elméleti séma alapján történő interpretálásának lehetőségét. Erre utal például a különböző kódolási rendszerek használata, vagy a MAXMaps által vizualizált elméleti modellek kreálása is (Kuckartz, 2010; Sántha, 2015).

A módszertani trianguláció a szoftverek használata mellett szóló legerősebb indok, hiszen a kvalitatív technikák kombinálása, az adatok elemzése ma már a modern szoftverek segítségével viszonylag gyorsan és látványosan kivitelezhető. Napjainkban a kvalitatív kutatások világában leggyakrabban alkalmazott három szoftver, az ATLAS.ti, a MAXQDA és az NVivo (Cisneros Puebla - Da- vidson, 2012) a szövegszintű (kódolás) és a fogalmi szintü (hálózatépítő) munka mellett lehetővé teszik ugyanazon projektben a multikódolt adatokat biztosító technikák (képek/fotók, audio- és videoadatok, különféle interjútipológiák, fotóinterjúk, megfigyelések, reflektív naplók és átirataik) párhuzamos megjelenítését és elemzését. Továbbá a szoftverekkel alkalmazhatók a deduktív, az induktív és kombinált logika szerinti kódolási szisztémák is.

A kvalitatív és a kvantitatív módszertani kombináció szintén releváns a szoftverek segítségével, lehetőség van az SPSS-sel és az Excel-lel való kapcsolat kiépítésére is. Mindezt például a MAXQDA a Mixed Methods menüpontban kínálja, továbbá számos esetben Excel-kimenetet is biztosít.

A személyi trianguláció érdekében a MAXQDA használatakor különböző kutatók ugyanazt az adatkorpuszt vagy annak egy részét egymástól függetlenül elemezhetik (Kuckartz, 2010). A MAXQDA lehetőséget nyújt az interkódolás szerinti megbízhatósági index meghatározására, amikor több kódoló ugyanazon rendszer alapján kódolja ugyanazt a dokumentumot (Sántha, 2013). Ez kutatói teammunkában lehetséges. A szoftverhasználat megkezdése előtt, bejelentkezéskor meg kell adni a felhasználó ismertetőjegyeit (pl. név kezdőbetűit), ami alapján a program azonosít és a különféle dokumentumokban folytatott munkát nyomon követi.

Általános értelmezés szerint az adatok triangulációja eltérő időpontban és helyen, különböző forrásból, más és más személyektől, valamint különböző technikai megvalósítással gyüjtött adatokkal történő munkát jelenti. A különféle helyről és eltérö időpontban gyüjtött kvalitatív adatok kezelése szintén megvalósítható a MAXQDA segítségével: az adatok dokumentumcsoportként kezelhetők és együtt vagy akár külön is elemezhetők (Kuckartz, 2010).

A MAXQDA lehetővé teszi a kvantitatív és a kvalitatív módszerekkel gyüjtött adatok közötti linkkapcsolatok kiépítését. Minden objektum kódolható, memóval látható el, valamint a kvalitatív adatok kvantitatív adatokká transzformálhatók. Felhívjuk a figyelmet a dokumentumlinkekre, melyek a projekten belüli dokumentumok közötti kapcsolatot biztosítják, továbbá a belső dokumentumok és a projekten kívüli elemek társítását segítő külső linkek, valamint a Google Earth számítógéppel támogatott kvalitatív adatelemzésbe történő bekapcsolásával müködő geolinkek szintén segítik a kvalitatív vizsgálatok többdimenzionalitásának biztosítását, az adatok triangulációját (Sántha, 2016a).

Tegyük fel, hogy egy iskolaépület mikro- és makrokörnyezetének elemzésére fókuszálunk és az adatok triangulációjára törekszünk. Ekkor többféle forrás állhat rendelkezésre: az iskoláról megfigyeléseket végezhetünk, interjút készíthetünk az intézmény tanáraival, diákjaival, a szülökkel, korabeli vagy aktuális újságcikkeket, fotókat kereshetünk, valamint alapozhatunk a modern technika által kínált lehetőségekre, a Geographic Information System (GIS) adataira is. Így az épület földrajzi paramétereinek, GPS-koordinátáinak függvényében az iskoláról müholdas vagy utcai nézeteket ábrázoló felvételek birto- 
kába kerülhetünk. E sokoldalú megközelítéssel az eredmények teljesíthetik a komplementaritás elvét, vagyis kiegészíthetik egymást és hozzájárulhatnak a téma alapos feltárásához. Az adatok triangulációjának szoftverekkel támogatott kutatási környezetben való illusztrálására kiváló példát találunk Vámos (2013) empirikus vizsgálatában (Sántha, 2016b).

\section{Összegzés}

A tanulmányban vizsgált tartalmi csomópontok megerősítik azt, hogy a szoftverek empirikus vizsgálatokban történő alkalmazása növeli a kvalitatív vizsgálatok módszertani tudatosságát, hiszen a különféle szoftverek rendszerezik, könnyen átláthatóvá teszik az adathalmazt, képesek az elemzési folyamat gyorsítására. A trianguláció-tipológiák a többdimenzionalitás mellett segítik a kvalitatív metodológiai követelmények érvényre juttatását is. Ezért a tanulmányban elemzett két markáns tartalmi csomópont, a trianguláció és számítógéppel támogatott kvalitatív adatelemzés témakörének összekapcsolása hozzájárulhat a kvalitatív adatelemzés szisztematizálásához.

\section{Felhasznált irodalom}

Ackel-Eisnach, K. - Müller, C. (2012): Perspektiven-, Methoden- und Datentriangulation bei der Evaluation einer kommunalen Bildungslandschaft. Forum Qualitative Sozialforschung/Forum Qualitative Social Research, 13 (3), http://nbn-resolving.de/urn:nbn:de:0114-fqs120354. (letöltés ideje: 2012.10.03.).

Cisneros Puebla, C. A. - Davidson, J. (2012): Qualitative Computing and Qualitative Research: Addressing the Challenges of Technology and Globalization. Forum Qualitative Sozialforschung/Forum Qualitative Social Research, 13 (2), http://nbn-resolving.de/urn:nbn:de:0114-fqs1202285. (letöltés ideje: 2012.11.02.).

Denzin, N. K. (1989): The Research Act: A Theoretical Introduction to Sociological Methods. New York: McGraw-Hill

Fielding, N. - Lee, R. (1991): Using computers in qualitative research. London: Sage

Flick, U. (2005): Wissenschaftstheorie und das Verhältnis von qualitativer und quantitativer Forschung. In: Mikos, L. - Wegener, C. (hrsg.): Qualitative Medienforschung: Ein Handbuch. Konstanz: UVK, 20-29. o.

Flick, U. (2008): Triangulation: Eine Einführung. Wiesbaden: VS Verlag

Flick, U. (2014): An Introduction to Qualitative Research. (ed.5.). London: Sage

Glaser, B. G. - Strauss, A. L. (1967): The Discovery of Grounded Theory: Strategies for Qualitative Research. Chicago: ABC

Horváth Dóra - Mitev Ariel (2015): Alternatív kvalitatív kutatási kézikönyv. Budapest: Alinea Kiadó
Király Gábor - Dén-Nagy Ildikó - Géring Zsuzsanna - Nagy Beáta (2014): Kevert módszertani megközelítések: Elméleti és módszertani alapok. Kultúra és Közösség, 5 (2), 95-104. o.

Kuckartz, U. (2010): Realizing Mixed-Methods Approaches with MAXQDA. www.maxqda.com/download/MixMethMAXQDA-Nov01-2010.pdf (Letöltés ideje: 2014.07.13.).

Kuckartz, U. (2012): Qualitative Inhaltsanalyse: Methoden, Praxis, Computerunterstützung. Weinheim und Basel: Beltz Juventa

Kuckartz, U. (2014): Mixed Methods: Methodologie, Forschungsdesign und Analyseverfahren. Wiesbaden: Springer Verlag

Kvale, S. (2005): Az interjú: Bevezetés a kvalitatív kutatás interjútechnikáiba. Budapest: Jószöveg Mühely Kiadó

Lamnek, S. (2005): Qualitative Sozialforschung. Lehrbuch. Weinheim: Beltz Verlag

Mason, J. (2009): Mixing methods in a qualitatively driven way. Qualitative Research, 1. 9-25. o.

Miles, M. - Huberman, A. (1994): Qualitative data analysis: An expanded source-book. Thousand Oaks, CA: Sage Publications

Reichertz, J. (2009): Die Konjunktur der qualitativen Sozialforschung und Konjunkturen innerhalb der qualitativen Sozialforschung. Forum Qualitative Sozialforschung/Forum Qualitative Social Research, 10. (3). http://nbn-resolving.de/urn:nbn:de:0114-fqs0903291. (Letöltés ideje: 2017.03.29.).

Richardson, L. (2000): Writing: A Method of Inquiry. In: Denzin, N. K. - Lincoln, Y. S. (eds.): Handbook of Qualitative Research. Thousand Oaks: Sage, 923-948. o.

Sántha Kálmán (2009): Bevezetés a kvalitatív pedagógiai kutatás módszertanába. Budapest: Eötvös József Könyvkiadó

Sántha Kálmán (2011): Abdukció a kvalitatív kutatásban: Bizonytalanság vagy stabilitás? Budapest: Eötvös József Kiadó

Sántha Kálmán (2013): Multikódolt adatok kvalitatív elemzése. Budapest: Eötvös József Könyvkiadó

Sántha Kálmán (2015): Trianguláció a pedagógiai kutatásban. Budapest: Eötvös József Könyvkiadó

Sántha Kálmán (2016a): Számítógéppel támogatott kvalitatív adatelemzés: kurzustervezet a neveléstudományi képzések számára. In: Károlyi Krisztina - Homonnay Zoltán (szerk.): Kutatások és jó gyakorlatok a tanárképzés tudós mühelyeiből. Budapest: ELTE Eötvös Kiadó, 25-36. o.

Sántha Kálmán (2016b): A neveléstudományi vizsgálatok új eleme: téri információk számítógépes feldolgozása. Eruditio-Educatio, 11 (1), 31-38. o.

Silverman, D. (2004): Interpretarea datelor calitative. Iaşi: Polirom

Smith, J. K. - Heshusius, L. (1986): Closing down the conversation: The end of the quantitative-qualitative debate among educational inquires. Educational Research, 15 (1), 4-12. o. 
Szénássy Barna (2004): Megjegyzések Gauss nemeuklideszi geometriai eredményeihez. In: Prékopa András - Kiss Elemér - Staar Gyula - Szenthe János (szerk.): Bolyai - Emlékkönyv. Bolyai János születésének 200. évfordulójára. Budapest: Vince Kiadó, 111-120. o.

Tesch, R. (1992): Qualitative Research: Analysis Types and Software Tools. New York: Palmer Press

Vámos Tibor (2013): Funkcionális terek vizsgálata egy kispesti szakközépiskolában: Iskolám, ahogy a di- ákok látják. Szakdolgozat. Székesfehérvár: Kodolányi János Főiskola

Verd, J. M. - Porcel, S. (2012): An Application of Qualitative Geographic Information System (GIS) in the Field of Urban Sociology Using ATLAS.ti: Uses and Reflections. Forum Qualitative Sozialforschung/Forum Qualitative Social Research, 13 (2), Art. 14. http://nbn-resolving. de/urn:nbn:de:0114-fqs1202144. (Letöltés ideje: 2012. 06.01.). 